\title{
Kenaf and Kenaf-Rubberwood Hybrid Particleboards
}

\author{
Juliana Abdul Halip, Lee Seng Hua, Paridah Md. Tahir, Syeed SaifulAzry Al Edrus, Siti \\ Mastura Md Ishak, Mohamad Ali Selimin, Abdullah Al Rashid Ab Hamid
}

\begin{abstract}
Kenaf (Hibiscus cannabinus) stem which consists of whole stem (KWS), core $(\mathrm{KC})$ and bast $(\mathrm{KB})$ were used to fabricate homogeneous and hybrid kenaf-rubberwood particleboards. Two types of panels namely homogeneous (100\%RW, 100\%KWS, 100\% KC and 100\% KB) and hybrid (70\%RW- 30\%KWS, 70\%RW- 30\%KC and 70\%RW$30 \% \mathrm{~KB})$ particleboards were manufactured and examined through compaction and void evaluations. Findings show that hybrid panels consisting of $70 \% \mathrm{RW}$ and $30 \% \mathrm{KWS}$ and homogeneous $100 \% \mathrm{KWS}$ give better compaction and less voids as compared to other homogenous and hybrid panels. The panel made from $100 \%$ KWS was observed to have more flattened and compressed cells compared to other homogeneous panels. A presence of $R W$ particle apparently reduces the void content and provides better compaction in the hybrid panels.
\end{abstract}

Index Terms: compaction, kenaf bast, kenaf core, kenaf whole stem, rubberwood, void

\section{INTRODUCTION}

Compaction ratio is one the factors that influence the quality characteristics of particleboard. Compaction ratio refers to the relation between panel density and wood density $[1,2]$. As stated by Sam-Brew \& Smith [3], more compaction is required to compress the fibers greater than their natural density. According to Maloney [2], the compaction rate of a typical particleboard must be at least 1.3 to ensure the densification needed for the formation of the board to occur.

In a recent study, high density particleboard contributes to high particles compaction that reduced the panel's gaps and

Revised Manuscript Received on December 22, 2018.

Juliana Abdul Halip, Faculty of Technology Management and Business, Universiti Tun Hussien Onn, 86400 Parit Raja, Batu Pahat, Johor, Malaysia.Corresponding author.Email: julianaah@uthm.edu.my

Lee Seng Hua, Institute of Tropical Forestry and Forest Products, Universiti Putra Malaysia, 43400 UPM Serdang, Selangor, Malaysia

Paridah Md. Tahir, Department of Forest Production, Faculty of Forestry, Universiti Putra Malaysia, 43400 UPM Serdang, Selangor, Malaysia. Corresponding author.Email:parida@upm.edu.my

Syeed SaifulAzry Al Edrus, Institute of Tropical Forestry and Forest Products, Universiti Putra Malaysia, 43400 UPM Serdang, Selangor, Malaysia

Siti Mastura Md Ishak, Department of Industrial Design, Faculty of Design and Architecture, Universiti Putra Malaysia, 43400 UPM Serdang, Selangor, Malaysia

Mohamad Ali Selimin, Faculty of Technology Management and Business, Universiti Tun Hussien Onn, 86400 Parit Raja, Batu Pahat, Johor, Malaysia

Abdullah Al Rashid Ab Hamid, Faculty of Technology Management and Business, Universiti Tun Hussien Onn, 86400 Parit Raja, Batu Pahat, Johor, Malaysia porosity of the particleboard, and attributed to the higher mechanical properties of wood species [4]. In addition, Dias et al [1] reported that the increase in the compaction rate of particleboards increased the mod-ulus of rupture and the modulus of elasticity, as well as low water absorption and thickness swelling values.

It is difficult to fabricate low-density particleboard using high-density raw wood material. Consumption of low-density lignocellulosic material namely kenaf is one of the solutions of having high compaction ratio of panel. Kenaf (Hibiscus cannabinus) has been grown in the tropical Africa as early as 4,000 BC. As stated by Paridah et al [5], kenaf has a long history of cultivation for its fibre in the India, Bangladesh, Indonesia, Thailand, Australia, U.S.A, Southeast Europe, some parts of Africa, and Brazil. Kenaf is an annual crop that is generally separated into two components, the long fibre as part of the bast, and the short fibre or known as core, which located at the inner part of the kenaf stem. These two distinct components have been reported to have different anatomies, chemical and mechanical properties.

Blending of low density and medium density particles namely rubberwood is one of the economical ways to promote kenaf as raw material. Therefore, in this study, homogeneous kenaf and hybrid kenaf-rubberwood were manufactured to evaluate the feasibility of kenaf parts through compaction and void studies.

\section{MATERIALS AND METHODOLOGY}

\section{A. Samples preparation}

Four- to five-month-old kenaf stem were obtained from National Tobacco Kenaf and Tobacco Board, Kelantan. Kenaf whole stems (KWS) were harvested, and some of the stems were manually peeled to separate the core $(\mathrm{KC})$ parts from the bast (KB). In this study, KWS, KC, KB (crude bast) and rubberwood (RW, as a control) were used as raw materials. Kenaf specimens were chipped and flaked using a Pallmann Mini Chipper and a Pallmann Knives Ring Flaker, respectively. Then, the fine particles were dried at 5\% moisture content before being sieved.

\section{B. Research Surface Methodology}

In this study, two types of panels were produced namely homogeneous

$(100 \%$ RW, 
$100 \% \mathrm{KWS}, 100 \% \mathrm{KC}$ and $100 \% \mathrm{~KB})$ and hybrid $(70 \% \mathrm{RW}-$ $30 \% \mathrm{KWS}, 70 \% \mathrm{RW}-30 \% \mathrm{KC}$ and $70 \% \mathrm{RW}-30 \% \mathrm{~KB}$ ) panels. A total of twenty one panels were made at dimension of 340 $\mathrm{mm} \times 340 \mathrm{~mm} \times 12 \mathrm{~mm}$. The particles were blended with $10 \%$ urea formaldehyde resin with a solid content of $65 \%$, and pressed in a hot press at a temperature of $160^{\circ} \mathrm{C}$ for $6 \mathrm{~min}$.

\section{Compaction study evaluation}

The presence of particle compactions in particleboards was observed using a stereo light microscope (Leica MZ 8) connected to an image analyzer. Meanwhile, for the image analyzer study, the samples were viewed under a stereo light microscope immediately after the samples had been oven dried and the images of compactions were then captured. Then, the images were analyzed using the graphic software CorelDRAW v10 to convert the images to graphic, producing clearer images. The total area of voids in the images obtained were visually estimated and quantified. Using image analysis software for area measurement, the areas of interest (voids) in the images were selected and the software then calculates the value of the areas. The voids which represent the darkest colours in the graphic was then visually recorded as following equation.

$$
\text { Void content }(\%)=\frac{\text { Void area }\left(\mu \mathrm{m}^{2}\right)}{\text { Area of interest }\left(\mu \mathrm{m}^{2}\right)} \times 100
$$

\section{RESULTS AND DISCUSSION}

\section{A. Compaction of homogeneous particleboard}

Fig. 1 shows the RW particles (a) before pressing, (b) after hot pressing and being captured using image analyzer, and (c) after hot pressing and analyzer using graphical software. After the hot pressing, the particles were compacted and bonded to each other. When they were analysed under image analyzer, the arrangement of both types of particles [see Fig.1 (b)] was found to complement each other and leave some voids. When the image was converted into graphic [see Fig. 1 (c)], the presence of voids was seen much clearer. The differentiation in the colours, i.e., bright grey (RW) and black indicates the voids between the particles.

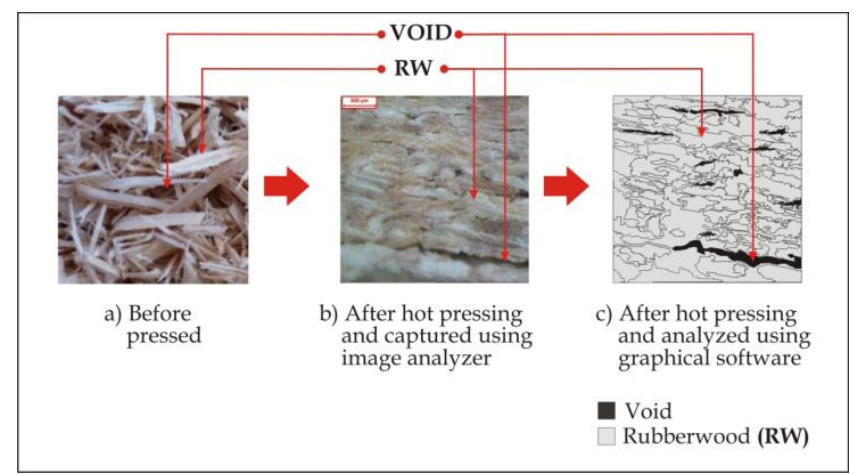

Fig.1: The compaction of particleboards made from 100\% rubberwood

Although the measurement and quantification of macro-voids are difficult [6], an estimation of the amount of voids can be made based on the area of graphic. Finding shows that $2.34 \%$ of voids were found to exist in the $100 \%$

RW particleboards. This relatively high void content was due to the low volume of the RW particles to having 0.70 $\mathrm{g} / \mathrm{cm} 3$ board density. However, the results for the performance of control boards $(100 \% \mathrm{RW})$ stated that this particular type of panels gave a superior strength due to its high density and slender particles shape [7]. In addition, under SEM observation, the RW panel with thicker cell wall was observed to be less compacted compared to kenaf core [8]. For this reason, the RW vessel was obviously less compressed compared to $100 \% \mathrm{KWS}$ and $100 \% \mathrm{KC}$ boards as shown by less flattened vessels.

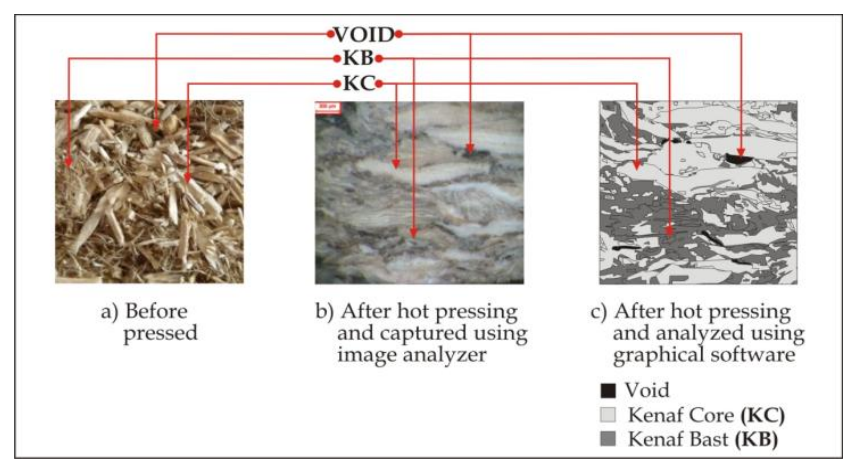

Fig. 2: The compaction of particleboard made from $100 \%$ kenaf whole stem

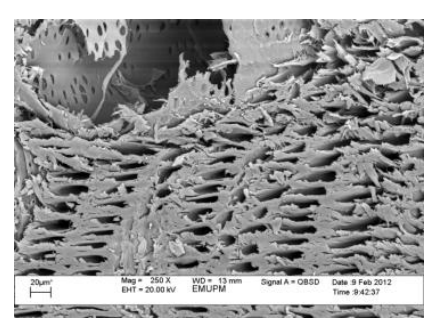

(a)

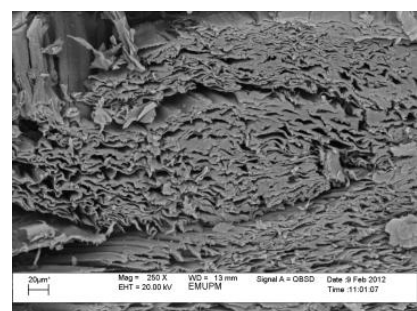

(c)

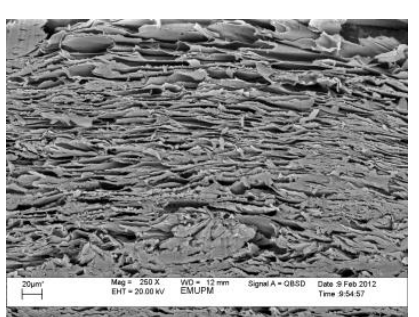

(b)

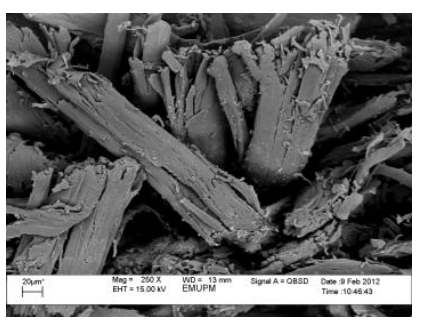

(d)

Fig.3: Comparison of compaction on (a) $100 \%$ RW, (b) $100 \% \mathrm{KWS}$, $100 \% \mathrm{KC}$ and $100 \% \mathrm{~KB}$ panels at 250x magnification [8]

The compaction of particleboard made from $100 \% \mathrm{KWS}$ is shown in Fig.2. It demonstrates that both $\mathrm{KC}$ and $\mathrm{KB}$ particles were randomly oriented, whereby the small particles contained mainly $\mathrm{KB}$ and some fines $\mathrm{KC}$ filling gaps between the larger ones (contained mainly $\mathrm{KC}$ ). After undergoing hot pressing, the existence of the $\mathrm{KC}$ and $\mathrm{KB}$ particles was observed to have better compaction with less voids, and eventually provided compatibility between $\mathrm{KC}$ particle, $\mathrm{KB}$ particle, and urea formaldehyde resin. Less void was obtained, as given by $0.50 \%$ void in $100 \% \mathrm{KWS}$, due to the increment in the particle volume.

The panel made from $100 \%$ KWS was observed to have more com-pressed cells

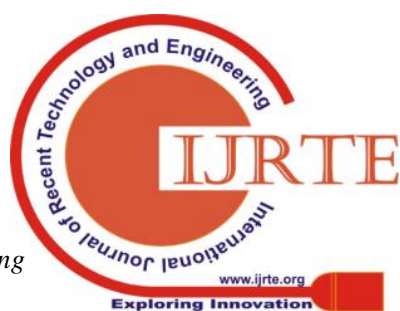


compared to the $100 \%$ RW panel (Fig. 3). Flattened cells were shown in Fig. 3, due to high compaction rate of $100 \% \mathrm{KWS}$ panel. Additionally, it was expected that the presence of stiff $\mathrm{KB}$ was capable to hold and retain the flattened cell of the $\mathrm{KC}$. For that reason, the presence of both $\mathrm{KC}$ and $\mathrm{KB}$ provides compact and strong panels of $100 \% \mathrm{KWS}$.

As illustrates in Fig. 4, a higher percentage of voids $(1.57 \%)$ be-tween the $\mathrm{KC}$ particles has perhaps encouraged fatigue and caused failure, especially during tensile test (internal bonding). As stated by Juliana et al [8], as compared to $100 \% \mathrm{KWS}$ panel, the cells of $100 \% \mathrm{KC}$ were apparently compressed but crumpled. Most of KC particles appear in stout and thick shapes [7]. These stout shapes and various geometries of $\mathrm{KC}$ create voids between the particles. When voids are abundance, there are lacks of intimated bonding among $\mathrm{KC}$ particles, and causes non-uniform load transfer from one particle to another. In addition, panel made from $100 \% \mathrm{KC}$ itself has a high volume of particles due to its low density, and thus, has a higher compaction rate as compared to other particleboard types. The higher compaction rate implies that there is more compressive deformation imparted onto the particles during hot pressing, and the particles are under greater compressive set [9]. This encourages stress to develop during hot pressing, where $\mathrm{KC}$ particles release moisture from the materials, while a large volume of the particles accelerates the stress of the panel and caused delamination [8].

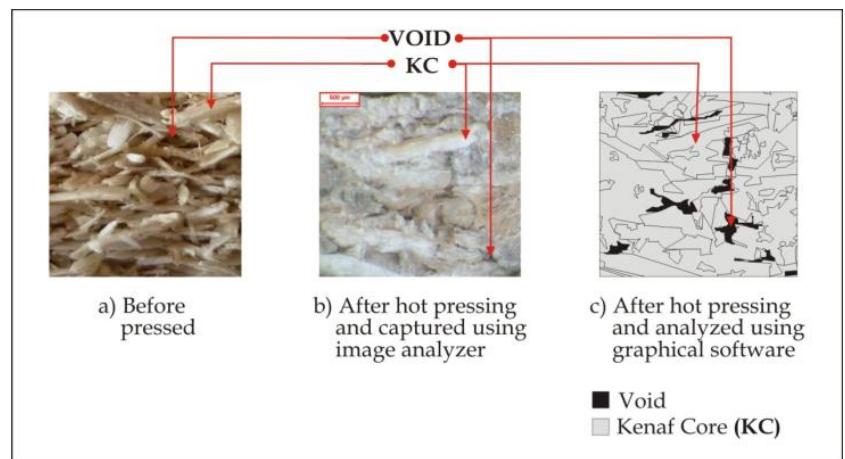

Fig. 4: The compaction of particleboards made from $100 \%$ kenaf core

However, such phenomenon occurred in $100 \% \mathrm{KWS}$ did not appear in the panel consisting of $100 \% \mathrm{KC}$. As shown in Fig. 3 (c), majority of low density and thin cell wall of kenaf core particle are observed to be crumpled. Therefore, the cell was observed to have uneven shape, probably collapsed and crumpled due to the soft and spongy parenchyma tissues. This particular characteristic enables $\mathrm{KC}$ to be easily compressed during the manufacturing process [10]. From the observation, there are more voids on the panel of $100 \% \mathrm{KC}$. In addition, the presence of various particle types, sizes and shapes assisted the gap filling on such panel and cause less voids in $100 \%$ KWS. According to Moslemi and Pfister [11], the dust and thin particles helped gap filling and increased the connection between the particles.

Voids in the panel are mainly around KC particles and they carry less load and are a source of crack propagation. As a result, $100 \% \mathrm{KC}$ gives low IB value $(0.09 \mathrm{~N} / \mathrm{mm} 2)$, whereby the value is significantly lower than $100 \% \mathrm{KWS}(0.51$ $\mathrm{N} / \mathrm{mm} 2$ ) [7]. According to Saad and Izran [12], a high amount of voids in wood composite contributes to lower strength and bonding in particleboards. This has also been supported by the finding of a study by Escobar [13], who reported that the void content of wood plastic composite with $50 \%$ and $65 \%$ of wood correlates well with MOR and MOE, whereby increasing void was found to have decreased the MOR and MOE values.

Thus, from observation, the board made from $100 \% \mathrm{~KB}$ was apparently loose, with more voids, and had less intimate contact among them, even after the hot pressing (Fig. 5). This indicates that there is less and no bonding at all among the KB particles. Therefore, $\mathrm{KB}$ was estimated to have as high as $8.04 \%$ void content. Apart from having poor wettability, hard and stiff $\mathrm{KB}$ particles cause less interparticle bonding and lead to the highest void content in $100 \% \mathrm{~KB}$ panel.

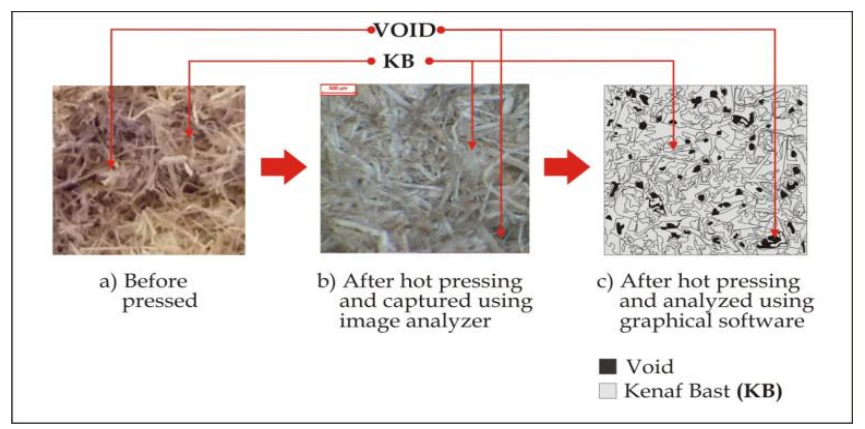

Fig. 5: The compaction of particleboard made from $100 \%$ kenaf bast

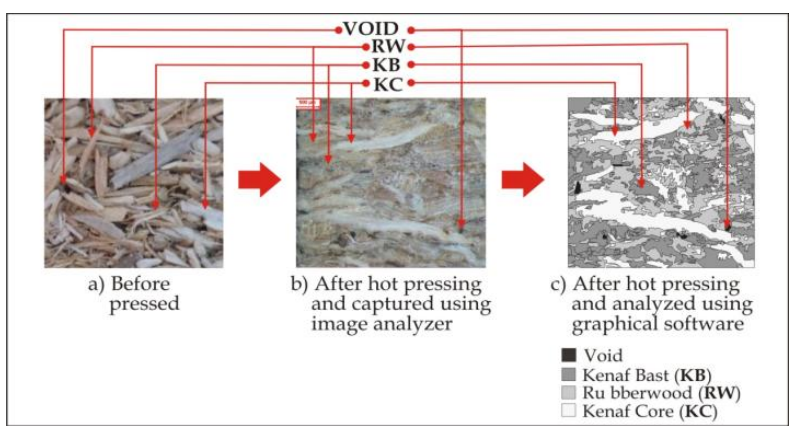

Fig. 6: The compaction of particleboard made from $70 \%$ rubberwood and $30 \%$ kenaf whole stem

From observation in Fig. 5, the KB particles are not well bond as there are less intimate contact. According to Escobar [13], when a stress is applied, a number of voids per unit area are sufficient to cause failure under stress and eventually give low strength properties on $100 \% \mathrm{~KB}$. Meanwhile, the existence of more voids may also provide spaces which encorage water uptake $[12,14]$. As the panel consisting $100 \%$ $\mathrm{KB}$ indicates the highest amount of voids, it helps to accommodate some of the swelling of the panel. Therefore, during water submersion, water molecules reside in the voids in the particleboard. Moreover, the hydroxyl and carboxyl groups that consist of cellulose and hemicelluloses are able to inter-act with water molecules via hydrogen bonding. This results in the increment of the water absorption and thickness swelling values of $100 \% \mathrm{~KB}$ panel. 


\section{Compaction of hybrid particleboard}

All the hybrid panels consist of $70 \%$ RW particle loading has less void content. Therefore, the admixture panels were anticipated to have better compaction and result in higher strength, bonding, and with decreased the thickness swelling and water absorption values. Apart from $100 \% \mathrm{RW}$ panel, the lowest void content $(0.25 \%)$ of $70 \% \mathrm{RW}-30 \% \mathrm{KWS}$ particleboard provided the best mechanical and physical properties among the hybrid and homogeneous panels (Fig. 6). This value was shown to be slightly lower than any homogeneous panel. As discussed previously, good particle characteristics of RW in the hybrid panels enhanced the compaction of kenaf based particleboards. This could be seen through the reduction of void content on the cross section of the $70 \%$ RW-30\%KWS panel [Fig 6 (c)].

In a hybrid $70 \% \mathrm{RW}-30 \% \mathrm{KWS}$, the presence of three types of particle (namely, RW, KC, and $\mathrm{KB}$ ) gives a better compactness in higher magnification. Apparently, this panel shows good inter-particle bonding between each type of the particles, where the diffentiation of particles is rather difficult to observe. It is why the bonding strength of this particular panel shows the most superior IB among the kenaf based particleboards and this value shows that there is about $76 \%$ increment in the bonding strength when the KWS particles are mixed with the RW particles. Therefore, it can be said that panels made from a combination of $70 \% \mathrm{RW}$ and $30 \%$ (w/w) KWS evidently gave the best combination. Because of the reasons explained earlier, the combination of the three different woody materials of different sizes and shapes had benefitted and enhanced the structure of the panels.

As for the hybrid of kenaf-rubberwood boards, namely, $70 \%$ RW-30\% KC and 70\%RW-30\% KB (Figs. 7 and 8), the void contents are approximately $1.25 \%$ and $6.97 \%$, respectively. These indicate that the void content, especially in the $70 \% \mathrm{RW}-30 \% \mathrm{~KB}$ panel, is markedly higher as compared to that of the $70 \% \mathrm{RW}-30 \% \mathrm{KWS}$ panel. This higher void content, in $70 \% \mathrm{RW}-30 \% \mathrm{~KB}$ panel is probably due to the properties of the KB particles, which are high in density, thin but hard to wet inhibit the bonding between $\mathrm{KB}$ and RW particles. Therefore, some poor inter-particle bonding conditions finally result in an important source of void generation. From Figs. 7 and 8, less compaction and more voids can be observed, even in the presence of the RW particles. Although the voids of $70 \% \mathrm{RW}-30 \% \mathrm{KC}$ and $70 \% \mathrm{RW}-30 \% \mathrm{~KB}$ are comparable to those homogeneous $100 \% \mathrm{KC}$ and $100 \% \mathrm{~KB}$ panels, the strength of the admixture board was significantly increased. This could probably be due to the presence of a high percentage of the RW particles $(70 \% \mathrm{w} / \mathrm{w})$, together with high material density, slender particles, and good mechanical properties of RW particles, which are capable to provide strength to these panels.

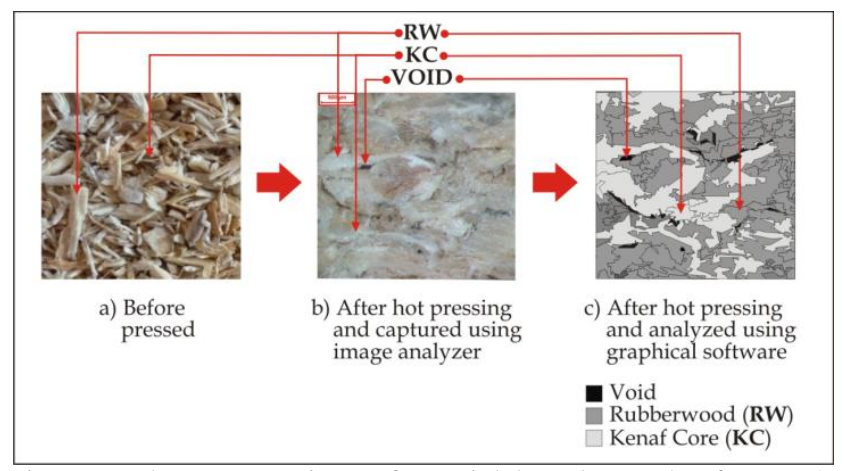

Fig. 7: The compaction of particleboards made from $70 \%$ rubberwood and $30 \%$ kenaf core

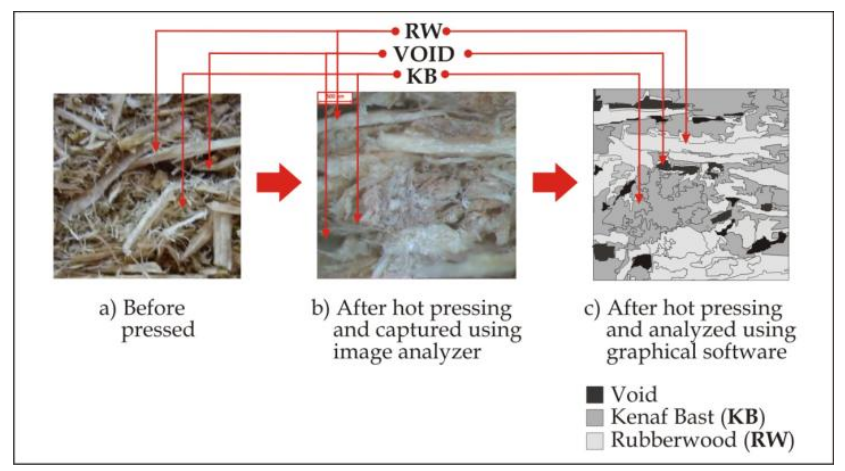

Fig. 8: The compaction of particleboards made from $70 \%$ rubberwood and $30 \%$ kenaf bast

The thermosetting resin (urea formaldehyde) used in this study is polar, which is chemically compatible with cellulose [15]. Urea formaldehyde resin is also known to be acid-catalyzed and cannot attain an optimum state of cure in a low acid environment [16]. Therefore, it is predicted that the better acidity properties of RW particles help to improve the ability of the particles and acid setting UF resin to bond. Such an improvement probably increases and uniformizes the board density, and particle to particle bonding, which also results in higher strength. As evident, the internal bonding of the hybrid panels leads to improvement, especially in IB, where the bonding strength was found to significantly increase about $76 \%, 366 \%$, and $1162 \%$ in the 70RW-30KWS, 70RW-30KC, and 70RW-30KB, respectively, as compared to $100 \%$ homogeneous panels. This improvement correlates well with the strength properties, whereby the MOR and MOE values increase when the IB increases.

\section{CONCLUSIONS}

In conclusion, homogenous panel consisting of $100 \% \mathrm{KWS}$ gives better compaction and less voids as compared to other homogenous boards. Meanwhile, the hybrid panels of $70 \%$ RW-30\%KWS have shown good compaction and bonding among them. The results showed that KWS is more suitable to be used as a raw material for particleboards than $\mathrm{KB}$ and $\mathrm{KC}$. Hence, it is not necessary to separate the $\mathrm{KB}$ and $\mathrm{KC}$ from KWS for particleboard manufacture. This is because incorporating RW and KWS at 70-30 significantly im-proved the properties of the resulting particleboards. 


\section{AUTHORS PROFILE}

\section{ACKNOWLEDGMENT}

The authors thank the Economic Planning Unit (EPU), Office of the Prime Minister of Malaysia, for supporting the research with the EPU Kenaf scheme grant. The authors would like also thanks the Institute of Tropical Forestry and Forest Products (INTROP), University Putra Malaysia, for providing the authors with the facilities.

\section{REFERENCES}

1. F.M. Dias, M.F.D. Nascimento, M. Martinez-Espinosa, F.A.R. Lahr, and I.D.D. Valarelli, "Relation between the compaction rate and physical and mechanical properties of particleboards," Materials Research, vol.8, 2005, pp. 329-333.

2. T.M. Maloney, Modern particleboard and dry process fiberboard manufacturing. Forest Products Society, Madison: Wisconsin, 1993.

3. S. Sam-Brew, and G.D. Smith, "Flax and hemp fiber-reinforced particleboard," Industrial Crops and Products, vol.77, 2015, pp. 940-948.

4. A.M. Souza, M.F. Nascimento, D.H. Almeida, D.A.L. Silva, T.H. Almeida, A.L. Christoforo, and F.A. Lahr FA, "Wood-based composite made of wood waste and epoxy based ink-waste as adhesive: A cleaner production alternative," Journal of Cleaner Production, vol.193, 2018, pp. 549-562.

5. M.T. Paridah, B.A. Amel, S.O.A. SaifulAzry and A. Zakiah, "Retting process of some bast plant fibres and its effect on fibre quality: A review," BioResources, vol.6, 2011, pp. 5260-5281.

6. B, Zhang, Q, Wu, L, Wang, and G. Han, Characterization of internal void structure of strand-based wood composites using X-Ray tomography and digital tools, In Proceeding of the McMat2005 - The 2005 joint ASME/ASCE/SES Conference on Mechanics and Materials, June 1-3, 2005. Baton Rouge: Los Angeles.

7. A.H. Juliana, M.T. Paridah, S. Rahim, I. NorAzowa, and U.M.K. Anwar, "Properties of particleboard made from kenaf (Hibiscus cannabinus L.) as function of particle geometry," Journal of Materials and Design, vol.34, 2012, pp. 406-411.

8. A.H. Juliana, M.T. Paridah, A.C.Y. Choo, and A. Zaidon, "Effect of kenaf parts on the performance of single-layer and three-layer particleboard made from kenaf and rubberwood," BioResources, vol.9, 2014, pp. 1401-1416.

9. E.D. Wong, M. Zhang, Q. Wang, and S. Kawai S, "Formation of density profile and its effects on the properties of particleboard," Journal of Wood Science and Technology, vol.33, 1999, pp. 327-340.

10. S.J.J. Lips, G.M. Iniguez de Heredia, R.G.M. Op den Kamp, and J.E.G. Van Dam, "Water absorption characteristics of kenaf core to use as animal bedding material," Journal of Industrial Crops and Products, vol.29, 2009, pp. 73-79.

11. A.A. Moslemi, and SC. Pfister, "The influence of cement/wood ratio and cement type on bending strength and dimensional stability of wood-cement composite panels," Wood and Fiber Science, vol.19, 1987, pp. 165-175.

12. M.J. Saad, and K. Izran, "Mechanical and physical properties of low density kenaf core particleboards bonded with different resins," Journal of Science and Technology, vol.4, 2012, pp. 17-32.

13. W.G. Escobar, Influence of wood species on properties of wood/HDPE composites. Ph. D. thesis, Washington State University, United States, 2008.

14. Y.W. Loh, P.S. H'ng, S.H. Lee, W.C. Lum, and C.K. Tan CK, "Properties of particleboard produced from admixture of rubberwood and mahang species," Asian Journal of Applied Science, vol.3, 2010, pp. 310-316.

15. M.Y. Nor Yuziah, Research and Development Manager, Malaysian Adhesives and Chemicals Sdn. Bhd., Shah Alam, Selangor, personal communication, September 2012.

16. W.E. Johns, and K.A. Niazi, "Effect of pH and buffering capacity of wood on gel time of UF resin," Wood Fiber, vol. 30, 1980, pp. 255-263.

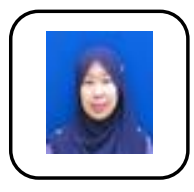

Juliana Abdul Halip is a senior lecturer from Faculty of Technology Management and Business, Universiti Tun Hussien Onn, majoring in biocomposite science. To date, she has published more than 30 articles in numerous journals, book chapters, proceedings etc.

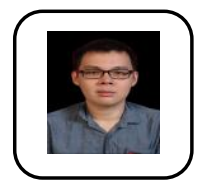

Lee Seng Hua is a research fellow from Institute of Tropical Forestry and Forest Products, Universiti Putra Malaysia, majoring in wood science and technology. To date, he has published more than 80 articles in numerous journals, book chapters, proceedings etc.

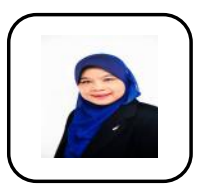

Paridah Md Tahir is a professor from Institute of Tropical Forestry and Forest Products, Universiti Putra Malaysia, majoring in biocomposite science. To date, she has published more than 290 articles in numerous journals, book chapters, proceedings etc.

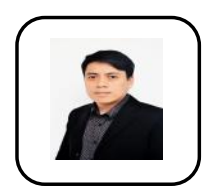

Syeed SaifulAzry Al Edrus is a research officer from Institute of Tropical Forestry and Forest Products, Universiti Putra Malaysia, majoring in nanocomposite science. To date, he has published more than 20 articles in numerous journals, book chapters, proceedings etc.

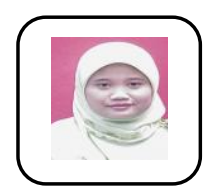

Siti Mastura Md Ishak is an assistant professor from Department of Industrial Design, Faculty of Design and Architecture, Universiti Putra Malaysia, majoring in industrial design. To date, she has published more than 10 articles in numerous journals, book chapters, proceedings etc.

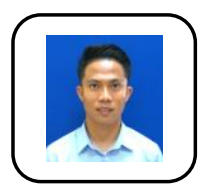

Mohamad Ali Selimin is a senior lecturer from Faculty of Technology Management and Business, Universiti Tun Hussien Onn, majoring in mechanical engineering. To date, he has published more than 15 articles in numerous journals, book chapters, proceedings etc.

Abdullah Al Rashid Ab Hamid is a lecturer from Faculty of Technology Management and Business, Universiti Tun Hussien Onn, majoring in forest production and products. To date, he has published more than 10 articles in numerous journals, book chapters, proceedings etc. 